\title{
Counterfeiting of medicines as an infringement of the intellectual property rights
}

\author{
Filip Cvetanovski, Katerina Brezovska*, Ana Poceva Panovska, Jelena Acevska, \\ Jasmina Tonic Ribarska, Zoran Sterjev, Aleksandra Grozdanova, \\ Katerina Ancevska Netkovska
}

Faculty of Pharmacy, University Ss. Cyril and Methodius, Majka Tereza 47, 1000 Skopje, Republic of Macedonia

Received: July 2016; Accepted: August 2016

\begin{abstract}
Counterfeiting and piracy are one of the biggest issues of the global economy in the last two decades, facing all industrial sectors, including pharmaceutical industry. Counterfeiting of medicines is a growing phenomenon affecting all type of medicines including both innovative and generic and represents a serious public health problem and a problem of the trade competition as an intellectual property right infringement. In order to combat this problem, anti-counterfeit regulatory activities are undertaken on a global level through establishment of legislation, strengthening the regulatory activities, development of mechanisms for effective collaboration between the stakeholders on national and international level and communication for raising public awareness regarding the risk of using counterfeited medicines. The role of the pharmaceutical manufacturers, wholesalers and retailers in the fight against counterfeited medicines is essential for securing the supply chain and providing quality, safety and efficacy of the medicines that reach the patients from one side and for protecting their brands and their profit from the other side.
\end{abstract}

Key words: intellectual property rights, counterfeiting, medicines

\section{Background}

Intellectual property represents the rights given to people over the creations of their minds, usually given as an exclusive right over the use of his/her creation for a certain period of time. Intellectual property rights include copyright and rights related to copyright, with a main social purpose to encourage and reward creative work; and industrial property, aiming to stimulate and ensure fair competition and to protect consumers, but also to stimulate innovation, design and the creation of technology. Industrial property includes protection of trademarks and geographical indications, but also inventions (protected by patents), industrial designs and trade secrets. The social purpose is to provide protection for the results of investment in the development of new technology, thus giving the incentive and means to finance research and development activities (WTO, 1994). The fast growth of the counterfeiting and piracy as an intellectual property infringement in the last two decades, have created one of the biggest problems facing all sectors of the global economy (OECD, 2011). The damage inflicted on the businesses can be seen through: loss of income, product withdrawal, loss of the brands' value etc. Counterfeiting also causes social problems like: indirect tax rises, market destabilization, criminal activity, downsizing of foreign investments, expenses for exercising of intellectual property rights etc. (OECD, 1998).

According to the World Trade Organization (WTO), counterfeiting is unauthorized representation of a regis-

\footnotetext{
*kami@ff.ukim.edu.mk
} 
tered trademark carried on goods identical or similar to goods for which the trademark is registered, with a view to deceiving the purchaser into believing that he/she is buying the original goods (WTO, 1994). Reports from the World Customs Organisation suggest that around $10 \%$ from every product/service sold all around the world are falsified. The data on counterfeiting and piracy presented in the 2013/2014 Illicit trade report, indicate that more than half of the reported cases were illicit pharmaceutical products, followed by electronic appliances, food, toys, games and school supplies; products representing a potential health and safety risk for the consumers. Compared to the data from 2012 there is a significant increase (from $10.21 \%$ to $76.42 \%$ ) in the reported cases of pharmaceuticals. The data regarding the falsified medicines include reported cases of many different types of medicines indicating that no medicine is safe from being counterfeited, including both innovative and generic, from life-style medicines to medicines that are indicated in life threatening diseases such as cancer, malaria and HIV. In the last years there is a significant increase in counterfeiting of dietary supplements (especially sliming dietary products) and medical devices. The phenomenon is increasing in the last few years, due to the growth of the sophistication of methods of falsification, and increased quantity of the imported products. According to the World Health Organization (WHO) around 10\% of the medicines are falsified on a global level, $30 \%$ to $60 \%$ are in the developing countries, around $1 \%$ of the falsified medicines enter in the legitimate distribution chain in the developed countries, and around 50\% from the medicines sold over internet are falsified. Counterfeiting of medicines is a highly profitable business with an estimated profit of more than 75 billion USD per year globally, resulting in a significant percentage of loss of the income of the pharmaceutical industry (WHO, 2010; WCO, 2013; WCO, 2014; WHO, 2014).

Innovative pharmaceutical and biopharmaceutical companies usually spend an average of $15-17 \%$ of their annual incomes on the research and development for providing the quality, safety and efficacy of their products and for ensuring the best outcome of the use of the medicine, avoiding the risk to the health and lives of patients (Blackstone et al., 2014; OECD, 1998). Counterfeiting of medicines as an unauthorised use of the intellectual property of the pharmaceutical industry reduces the incentives for creation and innovation, resulting in the damage to the economy, society and environment (Blackstone et al., 2014). From the other point of view, counterfeit medicines may include products with the correct ingredients or with the wrong ingredients, without active ingredients, with insufficient (inadequate quantities of ingredient(s) or with fake packaging and are often produced by unqualified personnel and in very poor and unhygienic conditions, and may contain toxic ingredients or unknown impurities, posing a serious treats to the health and safety of the patients. Consequently, counterfeiting of medicines has negative influence of the healthcare systems on an international level. Patients suffer from additional conditions due to the uncontrolled quality and quantity of the counterfeit medicine and therefore must get additional care covered by the state's ministry of health, causing additional burden of the government's funds (WHO, 2014).

The counterfeiting of medicines compromises the legitimate activities performed during the production, transportation and distribution, such as, infringement of the patent rights (unauthorised production, theft, selling and importation of patented active pharmaceutical ingredient), implementation of patented process or method for production of active pharmaceutical ingredients, excipients or finished products, unauthorised use of the name or logo patented for the medicine, the colour and shape of the dosage form, the packaging or any other characteristic that are subject of patenting. Counterfeiting of the medicines may involve unauthorized manufacturers, brokers, illegal/unregulated suppliers, wholesalers, and unregulated internet sale (MHRA, 2012; OECD, 2007).

\section{Anti-counterfeit regulatory activities on a global level}

Counterfeiting of medicines is an organized crime, reaching truly global proportions, which violates the law regarding the medicines and medical devices, but also includes infringement of the intellectual property rights of the pharmaceutical industry. The greatest concern regarding the counterfeit medicines is the risk to public health, therefore this problem should be considered primarily from a public health perspective, and secondary as an intellectual property concern (Council of Europe, 2013; WHO, 2014). The real extent of the problem with occurrence and distribution of counterfeit medicines vary from country to country. The lack of resources/skills to detect counterfeit medicines, weak medicines regulatory systems, the different definitions of counterfeit medicines in different countries worldwide, the variations in the distribution systems, high prices of the authentic medicines and insufficient cooperation between stakeholders are factors which facilitate counterfeiting activities (WHO, 1999).

Since the problem with counterfeit medicines cannot be combated successfully with isolated measures, an integrated and multilateral approach is necessary; ensuring cooperation between the various authorities involved, such as public health authorities and medicines agencies, as well as customs and police authorities on national, regional and international level. The fight against counterfeiting of medicines should also involve pharmaceutical manufacturers, distributors, health professionals, consumers and general public (Council of Europe, EDQM, 2013; MHRA, 2012; WHO, 1999).

The World health organization (WHO) in February 2006 founded the International Medical Products AntiCounterfeiting Taskforce (IMPACT), by joining together 
all of the stakeholders (international organizations, regulatory agencies, associations of pharmaceutical manufacturers, regulatory bodies) in the fight against counterfeit medicine on a global level, with the main purpose to provide the main principles and elements of the national legislation for combating this problem. IMPACT is focused on the establishment, implementation and enforcement of the legislation and regulatory infrastructure, development of the technology to prevent and to detect counterfeit medicines and communication strategy for rising public awareness (WHO, 2008).

The Medicrime convention of the Council of Europe is a powerful tool against the counterfeiting of medicines, from the perspective of protection of the patients' health. The Medicrime convention provides the guidance for introduction of common minimal standards for safety, efficacy and quality of medicinal products, essential and procedural criminal law; administrative procedures and preventive measures as well as provisions directed towards improving the cooperation and exchange of information between the entitled organs in the fight against counterfeit medicines (Council of Europe, 2013).

The intellectual property rights are mostly regulated on the national level, but additionally from an international perspective, the Trade related Aspects of Intellectual property rights (TRIPS) Agreement is also applicable. The TRIPS agreement is a document that guides the implementation of a global system for protection of the intellectual property rights, developed by the WTO and establishes minimal standards for legal protection of intellectual property rights (sanctions for criminal activities are not harmonized). The TRIPS agreement introduced intellectual property law into the international trading system for the first time and remains the most comprehensive international agreement on intellectual property to date. Specifically, TRIPS requires WTO members to provide copyright rights, geographical indications, industrial designs, patents, trademarks and undisclosed or confidential information. TRIPS specifies enforcement procedures, remedies, and dispute resolution procedures. According to TRIPS, the protection and enforcement of all intellectual property rights will contribute to the promotion of technological innovation and to the transfer and dissemination of technology, to the mutual advantage of manufacturers and users of technological knowledge, while maintaining the social and economic welfare, and balancing the rights and obligations of the holders if intellectual property rights (WTO, 1994).

\section{Protection of the brand of the pharmaceutical industry}

In order to protect their brands, many pharmaceutical companies take measures for prevention of counterfeiting and for rapid and effective response to counterfeited products including: development of the strategy for protection from counterfeit, establishment and protection of their intellectual property rights, developing standards for traceability of the authenticity of their products, and therefore providing larger transparency of the distribution chain and early detection of counterfeited products. The companies should continuously implement new anti counterfeiting technologies for securing the distribution chain and to protect their brands by using track and trace systems, serialization and by keeping electronic records for all stages of the distribution of their products. Many different anticounterfeit technologies are applied by the pharmaceutical companies including human readable (overt) and machine readable (covert) safety features, use of sophisticated printer inks and track and trace software (Abel, 2010; OECD, 2007). EU Directive 2011/62 provides for measures to prevent the entry into the legal supply chain of falsified medicinal products by requiring the placing of safety features consisting of a unique identifier and an anti-tampering device on the packaging of certain medicinal products for human use for the purposes of allowing their identification and authentication (Council of Europe, 2011). The new EU regulation 2016/161 sets out the system for identification and confirmation of the authenticity of the medicines (Unique Identifier, UI and Anti tampering device, ATD) in the distribution chain in order to in order to verify the legitimacy of the manufacturer (Council of Europe, 2015).

The pharmaceutical companies should establish testing laboratory units in different countries for examination of suspected counterfeit samples. Additionally, in the fight against counterfeit medicines the pharmaceutical industry should participate trough organizing trainings (for law enforcement, government officials, pharmacists and official testing laboratories), but also attending educational programs for detection, monitoring and reporting of counterfeit medicines; leading and supporting networks against counterfeiting for promoting knowledge and experience exchange, development of activities for communication, informing, education and awareness increase of the general public; establishment of cooperation between private and public institutions (Abel, 2010; OECD, 2007).

The wholesalers has also an important role in prevention of counterfeiting of medicines, by verifying the authenticity of the medicinal products in his physical possession and in cases where the verification of the safety features of the medicinal product indicates that the product may not be authentic or its packaging has been tampered, to report it to the relevant competent authorities (Council of Europe, 2015).

The marketing authorisation holder, parallel importers or parallel distributors are also an important link in securing the distribution chain of medicines and should share the responsibility with other stakeholders in the fight against counterfeiting medicines (Council of Europe, 2015). 


\section{Conclusion}

Counterfeiting of medicines is a crime carried out using deception and other techniques typical of organized crime, posing a significant danger to global public health in developing as well as developed countries. Additionally, counterfeiting of medicines has negative influence to the health care systems as well as to the pharmaceutical industry, causing financial problems, loss of the value of the brands and reduced confidence in their products. Solving this problem and preventing counterfeiting of medicines require establishment legislation that will identify the counterfeiting of medicines as a serious crime and enforcement of effective penalties proportional with the consequences of this crime, strengthening the regulatory activities for securing the distribution chain of the medicines, establishment and improvement of collaboration between health authorities, police, customs and judiciary and development of communication strategy for raising public awareness for the risk of using counterfeit medicines. The role of the pharmaceutical manufacturers, wholesalers and retailers in the fight against counterfeited medicines is essential for both securing the supply chain to provide quality, safety and efficacy of the medicines that reach the patients from one side and to protecting their brands and their profit from the other side.

\section{References}

Abel, J., 2010. Prevent Counterfeiting in the Pharmaceutical industry. Pharmaceutical engineering. 30.

Blackstone, E. A., Fuhr, J. P., Pociask, S.M.A., 2014. The Health and Economic Effects of Counterfeit Drugs. Am. Health. Drug Benefits 7, 216-223.

Council of Europe, 2011. EU Directive 2011/62 of the European Parliament and of the Council amending Directive 2001/83/ EC, Official Journal of the European Union L 174/74-87.
Council of Europe, 2013. Council of Europe Convention on the counterfeiting of medical products and similar crimes involving threats to public health. Council of Europe Treaty series/211.

Council of Europe, 2015. Commission delegated regulation (EU) 2016/161 supplementing Directive 2001/83/EC of the European Parliament and of the Council L 32/1-27.

Council of Europe, European Directorate for the Quality of Medicines \& Healthcare (EDQM), 2013. Counterfeiting of medical products and similar crime ('medicrime')- A strategic approach to assist states in protecting the health of their citizens. Council of Europe/ EDQM., Strasbourg.

Medicines and Healthcare Products Regulatory Agency (MHRA), 2012. Falsified Medical Products Strategy, 2012-2015.

Organization for Economic Co-operation and Development (OECD), 1998. The Economic Impact of Counterfeiting 16$18,30-36$.

Organisation for Economic Co-Operation and Development (OECD), 2007. The Economic Impact of Counterfeiting and Piracy, Executive Summary.

World Customs Organization (WCO), 2014. Illicit Trade Report 2013, 61-72.

World Customs Organization (WCO), 2015. Illicit Trade Report 2014, 59-75.

World Health Organization (WHO), 1999. Counterfeit Drugs: Guidelines for the Development of Measures to Combat Counterfeit Drugs. Department of Essential Drugs and Other Medicines, World Health Organization, Geneva, Switzerland.

World Health Organization (WHO), International Medical Products Anti-Counterfeiting Taskforce (IMPACT), 2008. Counterfeit Drugs Kill.

World Health Organization (WHO), 2010. Growing threat from counterfeit medicines. Bull World Health Organ, Volume 88, Number 4. 241-320.

World Health Organization (WHO), 2014. General information on counterfeit medicines. WHO 2014.

World Trade Organisation (WTO), 1994. Agreement on TradeRelated Aspects of Intellectual Property Rights, Annex 1C of the Marrakesh Agreement Establishing the World Trade Organization. 


\title{
Резиме
}

\section{Фалсификување на лековите како повреда на правата на интелектуална сопственост}

\author{
Филип Цветановски, Катерина Брезовска, Ана Поцева Пановска, Јелена Ацевска, \\ Јасмина Тониќ Рибарска, Зоран Стерјев, Александра Грозданова, \\ Катерина Анчевска Нетковска
}

Фармацевйски факулиетеи, Универзииеей Св. Кирил и Метиояиј, Мајка Тереза 47, 1000 Скойје, Рейублика Макеоонија

Клучни зборови: право од интелектуална сопственост, фалсификување, лекови

Фалсификувањето и пиратеријата се еден од најголемите проблеми на глобалната економија во последните две децении, со кој се соочуваат сите индустриски сектори, вклучувајќк ја и фармацевтската индустрија. Фалсификувањето на лекови е феномен во пораст и претставува сериозен проблем на јавното здравство од една страна и проблем на трговската конкуренција како повреда на правото од интелектуална сопственост од друга страна. Од различните типови на пријавени фалсификувани лекови е може да се заклучи дека ниеден лек не е безбеден од фалсификување, секогаш постои ризик било кој лек да биде фалсификуван, вклучувајќи ги и иновативните и генеричките лекови. Со цел да се спречи фалсификувањето на лекови се преземаат регулаторни активности на глобално ниво преку воспоставување на законодавството, зајакнување на регулаторните активности, воспоставување на механизмите за ефективна соработка меѓу засегнатите страни на национално и на меѓународно ниво, како и развивање на стратегија за комуникација со цел подигнување на јавната свест во врска со ризикот од употреба на фалсификувани лекови. Улогата на производителите на фармацевтски производи и дистрибутерите во борбата против фалсификуваните лекови е од суштинско значење за обезбедување на ланецот на снабдување со лекови за да се обезбеди квалитетот, безбедноста и ефикасноста на лековите од една страна и за заштита на своите брендови и профит од друга страна. 
